\title{
O CONHECIMENTO E A LEITURA FECUNDAM A TERRA LIVRE
}

\section{La connaisance et la lecture fertilisent la terre libre}

Marta Morais da Costa ${ }^{1}$

\section{Resumo}

Estuda-se a relação entre leitura, escola e conhecimento, numa linguagem que alterna a ficção com a dissertação, partindo da história da pesquisa realizada pelo Professor \& Leitor em uma biblioteca, com a finalidade de escrever um texto sobre definições de conhecimento, sua função e utilização na escola. Ao buscar nas estantes de livros, a personagem vai dialogando com filósofos, historiadores, educadores, psicólogos, dramaturgos e literatos, construindo uma rede de articulações de sentidos múltiplos para o conceito de conhecimento. Ao mesmo tempo, apresenta uma visão crítica sobre o estado da educação e seus comportamentos diante do saber e da necessidade de formação de alunos intelectualmente competentes.

Palavras-chave: Formação de professores; Leitura; Escola e conhecimento.

\section{Resume}

Ce travail étude la correspondance entre lecture, école et savoir, ecritdans un langage qui alterne la fiction et la dissertation, d' après l'histoire d'un Professeur \& Lecteur, qui fait des recherches dans une bibliothèque, pour écrire un texte sur les concepts de savoir, ses fonctions et son utilisation dans l' école. Au moment qu'il cherche les livres, le personnage dialogue avec des philosophes, des historiens, deséducateurs, despsychologues, des dramaturges et des écrivains, pour construire un réseau d'articulations aux sens multiples, destiné à définir le savoir. Simultanément, le travail présente une perspective critique de l' état de l' éducation et de ses allures au sujet du savoir etle besoin de donner une contribution à la formation d' élèves intelectuellement compétents.

Mots-clés : Formation de professeurs; Lecture; École et connaisance.

1 Doutora, professora do Mestrado e Doutorado em Estudos Literários da Universidade Federal do Paraná - UFPR. m.costa@pucpr.com.br 
A relação entre leitura e conhecimento implica, na escola, algumas considerações que alternam os escritos sobre as funções da instituição enquanto fomentadora de saberes, a intermediação do professor estimulando e criando acesso às fontes do conhecimento, e do beneficiário de todo o processo e trabalho de diferentes agentes, o aluno-aprendiz, dependente ocasional e promotor insubstituível da própria aprendizagem.

No percurso para se atingir a ciência e deixar para trás a ignorância o não saber - encontram-se balizas de diferente ordem e cuja função é a de indicar, registrar e demarcar a passagem do aprendiz rumo ao conhecimento. Essas balizas se posicionam em locais visíveis, quando o processo resulta em avanços consideráveis, comprovando que a aprendizagem se efetivou. Mas podem, ao contrário, se ocultar insidiosamente na neblina de procedimentos metodológicos mal pensados, sem amadurecimento, aplicados maquinalmente. Manipuladas por educadores despreparados, essas marcas acabam por indicar atalhos sem continuidade, caminhos já conhecidos e sem significação, massas de entulhos impedindo a passagem.

A aquisição do conhecimento não se descola do olhar do educador. De tal maneira está impregnada no cotidiano dos afazeres educacionais que, mesmo em atividades fora do ambiente escolar, o professor não esquece de sua função de possibilitar o acesso ao conhecimento. Por essa razão, o que vê, experimenta, capta como interpretações da realidade e lê nos livros tem caráter transitivo, isto é, transforma-se em exercício de preparo de aulas, formulação de atividades, aproveitamento escolar. Para o professor-educador, conhecer tem a ver com transmitir.

Integrante indissociável do processo é o aluno. Quando motivado a aprender, mobiliza-se pela curiosidade e para a pesquisa. Os confrontos e dificuldades que povoam o percurso da aprendizagem tornam-se úteis no crescimento pessoal, seja nos estudos seja na maturidade mental. Estudo, experiência e maturidade constituem componentes essenciais e complementares da sabedoria.

Nesse processo, a leitura é a forma mais eficaz, rápida e completa de acesso às informações que, absorvidas pelo indivíduo na forma de investimento significativo, tornam-se conhecimento. As novas tecnologias não a baniram. Mudaram os suportes, mas os textos continuam a desafiar os sujeitos leitores, cuja atuação recria os sentidos e faz viverem textos adormecidos, antes limitados à forma incompleta de significantes destituídos de significado, à espera da interação com leitores.

Essas reflexões servem como introdução explicativa para as aventuras de um leitor em busca do conhecimento. Imaginemos um professor, solicitado a tratar das relações entre a leitura e o conhecimento, saindo em busca das fontes para alicerçar seu desempenho docente e, talvez, expressá-lo em um texto. 
A necessidade de construir um pensamento coerente o impulsiona na direção da biblioteca, onde entra, aventureiro e ousado, para mais uma viagem de prospecção e pesquisa. Porque aprendeu que a solução para muitos problemas começa no diálogo com os livros. À medida que adentra 0 espaço da biblioteca, martela seu cérebro a lembrança de leituras anteriores. Uma delas dá conta que a escola é freqüentada por pessoas que nela buscam o conhecimento como forma de superar a pobreza material e pessoal. Estudar e obter um diploma significa para elas conquistar condições para destroçar a penúria e a marginalidade.

- Meu filho, você precisa estudar para ter uma vida melhor que a de seus pais. profissão!

- Minha filha, se você não estudar, não terá sucesso em nenhuma

Acentuando a fala, o dedo em riste, ameaçador, faz às vezes de um chicote a castigar por antecedência todos os pecados de preguiça e menosprezo ao estudo. Ai do pobre infeliz que ouse dizer:

- Mas eu não gosto de estudar. Eu odeio a escola!

Após o primeiro momento de assombro, os olhos do adulto faíscam, a voz treme, as palavras saem da boca em avalanche. São acusações, ameaças, predições de infortúnio, de desgraça e de derrotas. Esse pobre infeliz, apartado para sempre do conhecimento, será um pária social, um réu de morte cultural, um zero à esquerda da civilização. Para completar o quadro tenebroso, faltam só os raios celestes de mãos dadas com os trovões ensurdecedores, acompanhados da música de fundo dos filmes de terror, para completar o quadro da desgraça da ignorância.

Neste momento, o distraído leitor-professor chega, com olhos de apreensão, diante da bibliotecária que, solícita, o recebe:

- Posso ajudá-lo?

Retorna a si para agradecer e pedir autorização para navegar entre as estantes, em busca dos mares bravios da informação escrita que possam responder às indagações a respeito do conhecimento. Autorizado, desordenadamente mergulha entre os livros que o aguardam.

Ah, o perfume inconfundível de uma biblioteca! A imagem dos livros enfileirados, a se apoiarem mutuamente numa solidariedade sem igual entre os mortais! Nelas, as diferenças aproximam, as distâncias se reduzem, a irmandade predomina. A luz sempre suave vem conferir à imobilidade dos antepassados, não a rigidez da morte, mas a segurança e o repouso da missão de sabedoria já completada. Nessas estantes repousam, à espera de nossas vivas vozes, as vozes momentaneamente silenciadas de tempos e homens pretéritos. Dentre elas, renasce a de Jorge Luís Borges para nos advertir que "Sem uma eternidade, sem um espelho delicado e secreto do que passou pelas 
almas, a história universal é tempo perdido e nela nossa história pessoal - 0 que incomodamente nos transforma em fantasmas" (BORGES, 1991, p. 28).

O Professor \& Leitor prossegue a pesquisa e, ao acaso, toma o caminho dos filósofos, buscando encontrar a resposta para a compreensão do que seja o conhecimento. Platão o recebe para um banquete e de imediato expõe sua teoria sobre a transmigração das almas, na qual defende a idéia de que

(...) a alma, imortal e várias vezes renascida, tendo contemplado todas as coisas, tanto na terra como no Hades, não pode ter deixado de aprender tudo. Não é assim surpreendente que, sobre a virtude como sobre o resto, guarde recordações do que precedentemente já soube. Sendo toda a natureza homogênea e tendo a alma aprendido tudo, nada impede que uma só recordação (aquilo que os homens chamam saber) a faça redescobrir todas as outras, se for corajoso e tenaz na procura; porque a pesquisa e o saber não são mais que reminiscência (DROZ, S.d., p. 28).

Caso acreditemos nessa explicação para o conhecimento, seria necessário investir apenas na motivação que provocasse a memória, de vez que 0 aprendiz, despertado, encontraria a partir de si mesmo o saber. $O$ ensino seria assim "não a transmissão de um saber do exterior para o interior, mas antes a redescoberta por si mesmo e no interior de si de verdades escondidas e esquecidas" (Idem, p. 73).

O conhecimento adviria, portanto, de uma sabedoria acumulada, verdadeiro tesouro mantido sob a guarda dos antepassados, mas do qual se pode sacar quando necessário, desde que o aprendiz invista na tenacidade da procura. Este saber, que se considera acabado e delimitado, não atende à dinâmica do conhecimento, sempre em busca de estabelecer novas relações, para produzir novos conceitos, alterando o tesouro do já sabido. O contentamento com a plenitude pessoal, capaz de conter todas as verdades, assemelha-se a uma redução do saber ao limite do próprio umbigo.

Apesar da imobilidade contida nessa teoria, é possível descobrir em seus pressupostos básicos a integridade existente entre as várias gerações, de vez que o que procurássemos descobrir nos ligaria aos antepassados. Eles constituiriam uma força a dominar o presente. De alguma forma assim procedemos na escola ao recorrer freqüentemente ao saber acumulado pelo tempo. Ao citarmos, e procurarmos respaldo nas vozes já extintas, estamos recorrendo às fontes que acreditamos puras e definitivas. Ao insistirmos na importância da identificação como processo de compreensão do mundo, nada mais fazemos do que estabelecer a exclusividade do indivíduo como parâmetro das indagações e das respostas.

Mas, o conhecimento não terá mesmo esse caráter de autoconhecimento? A busca de mais e mais dados a respeito de realidades exteriores e 
interiores não visa, primordialmente, a esclarecer a nós mesmos de que matéria somos compostos, a que desígnios imprevisíveis somos sujeitos, quais as faces de nossa íntima natureza?

Em que sentido tomamos o termo conhecimento?

Numa definição fenomenológica, conhecer é o ato pelo qual um sujeito apreende um objeto. Já, segundo o modo de ver dialético, são operações do pensamento na elaboração da ciência. Seja qual for o conceito, a relação entre sujeito e objeto é primordial. Qualquer interrogação sobre 0 conhecimento traz como conseqüência a pergunta sobre o que seja a realidade. A partir dessa relação indissociável, podem ser estabelecidos alguns encaminhamentos para a reflexão.

O conhecimento é possível? Quando em sala de aula enfrentamos algumas mentes obstinadamente resistentes, olhares vagos e faces inexpressivas, assalta-nos a dúvida: "O que faço aqui? O que falha na comunicação entre mim e meu aluno? Como faço para penetrar, por intermédio do mundo sensível - olhos, ouvidos, tato - em sua mente e mostrar-lhe as visões de mundo que a humanidade já formulou?’.

Hesitamos entre uma posição cética - para a qual nada é passível de conhecimento - e uma postura dogmática, ao defender que os objetos são conhecidos da maneira como se oferecem aos sujeitos. Dogmaticamente moderados, podemos concluir que é possível conhecer, embora haja limites para o conhecimento, limites definidos por pressuposições e finalidades. $\mathrm{O}$ aluno indiferente ao conhecimento vive a limitação, determinada por um conjunto de circunstâncias familiares, sociais e físicas, que impõem obstáculos imensos no seu trajeto rumo ao saber.

E nosso Professor \& Leitor continua entre as estantes, atraído agora pelas lombadas dos livros, cada vez mais convidativas. A capa dura, em cores escuras, faz supor o saber mais denso e a maior relevância cultural, já que 0 texto exigiu uma proteção mais reforçada das páginas impressas. Ou será que o manuseio mais intenso do volume levou o setor de restauração da biblioteca a um trabalho de manutenção mais apurado?Qualquer que seja a explicação, trata-se de um livro em destaque. Os olhos são por ele atraídos de imediato; as mãos seguem o olhar e, sem demora, o volume se abre para a leitura. É Kant, para quem conhecer "é sobretudo constituir o objeto enquanto objeto do conhecimento". Nessa concepção transcendental, o sujeito assume posição de destaque, pois é o responsável pelo ato de constituir o objeto, atendendo a uma dupla compreensão da realidade: ou como sensível, isto é, formada por impressões e percepções que passam pelos sentidos, ou como inteligível, formada pelas idéias a respeito dos objetos.

No primeiro caso, a atitude do sujeito assemelha-se ao de Quindim, o rinoceronte do Sítio do Pica-pau Amarelo, para quem 
Esses assuntos científicos não me dizem nada. Nasci para comer e só me interesso por comida. De todas as histórias que ouvi, gostei apenas do tal Sinal de Raiz. Até me veio água na boca. Sou amigo de raízes - de mandioca, de inhame, todas. Quem sabe se essa raiz aritmética não é das gostosas? (LOBATO, 1974, p. 27)

É como se o rinoceronte representasse aquele aluno que, para conhecer, precisa comportar-se como São Tomé: limitado pelos cinco sentidos do corpo, incapaz de compreender a profundidade dos mistérios da vida. Mas podemos encontrar em D. Benta um outro parâmetro de conhecimento:

A inteligência do homem, de tanto observar os fenômenos, foi criando a ciência, que é o modo de compreender os fenômenos, de lidar com eles e produzi-los quando se quer. E o homem tanto fez que chegou ao estado em que se acha hoje - dono da terra, dominador da natureza, rei dos animais." (LOBATO, 1977, p. 8).

Podemos discordar da conclusão a que a gentil vovó chegou, se lembrarmos da continuada devastação da natureza, da desumanização e da violência com que o homem trata todos os seres vivos, inclusive a si próprio. Concordamos, contudo, com a valorização da inteligência, componente da razão e sede das idéias. Alternando e somando o empirismo - apoiado nos sentidos - e o racionalismo, vamos construindo a interpretação do mundo que nos cerca por meio das leituras que realizamos.

Aprendemos que qualquer representação sensível já constitui de certo modo e por si própria um conhecimento incipiente e, por isso, a atividade mental constituída de imagens, próximas das representações sensíveis e concretas, verificada em povos primitivos e nas crianças, resulta na natureza sensorial do conhecimento (PRADO, 1980, p. 60-61). Por isso, nos servimos da exploração visual e tátil dos livros de leitura, falseamos a voz, imitamos os pulos do sapo ao contar histórias. É o caminho inicial do conhecimento para quem começa a viajar nele. Embora esse não seja um privilégio das crianças: um jogador de futebol não tem consciência de todos os seus movimentos em campo durante uma partida, mas ele conhece a qualidade de seu jogo a partir de dados empíricos. Já o técnico pode, utilizando os dados concretos da realidade do jogo, abstrair esquemas táticos e conhecê-la mais a fundo.

Alguns volumes adiante, o Professor \& Leitor descobre, num pequeno dicionário de Filosofia, a referência a Nicolau de Cusa e à sua teoria dos 4 graus de construção do conhecimento:

1. o grau: os sentidos proporcionam imagens confusas e incoerentes;

2.. grau: a razão diversifica e ordena essas imagens; 
3. grau: o intelecto ou a razão especulativa unifica as imagens;

4.. grau: a contemplação intuitiva que, ao levar a alma a Deus, alcança o conhecimento da unidade dos contrários. (MORA, 1970, p. 81).

Inexplicavelmente, sobrepõe-se à leitura desse fragmento uma sensação desconfortável, semelhante à de um dever não cumprido, de uma prestação em atraso, de uma visita sempre adiada. Ela resulta da consciência da subutilização da mente humana. A escola, guardiã do conhecimento, consegue acionar quantos e quais desses graus? O primeiro deles, sem dúvida; é o primário. A aprendizagem sensorial herdada do instante da fecundação no útero materno, aprimorada ao longo dos anos, vem encontrar na sala de aula seu reforço e refinamento. Pensemos na insistência com que exigimos livros ilustrados - cada vez mais ilustrados. Pensemos na cobrança de poemas rimados e aliterados - e cada vez mais sonoros. Pensemos no descarte de textos longos, na recusa do léxico desconhecido, na preferência pelos textos de estrutura simples e narrativa linear. Considero a secundarização das idéias, como se fossem um estorvo ao pensamento, ou como se devessem apenas reproduzir os lugares-comuns, visando a facilitar tão somente o entendimento pelo leitor e a comunicação com ele.

Ajudamos a formar, assim, um leitor asséptico, que ama conviver com o limpo, com o depurado, com o previsível, com o clean mauricinho. Poupo-o das contradições, da tempestade cerebral, do ofício especulativo. Quando muito, incentivamos a ordenação, a classificação, a delimitação dos fatos e dos conceitos.

O que nos redime, enquanto docentes, é o dedo espetado do Joãozinho ou da Mariazinha a indagar o além do já dito e do já sabido. Como pequenos radares, esses questionadores inveterados buscam receber com antecedência a sua quota de informações e conceitos para alimentar as baterias do cérebro. Insidiosamente buscam avançar na cadeia do conhecimento, rompendo os limites impostos por nós e pelo sistema escolar, dedicado a dominálos. E porque permanece no patamar do primeiro estágio, o dos sentidos, a escola vem sendo substituída com vantagem pela televisão e pelo computador.

Contra essa compartimentalização do conhecimento, apresentam-se aos olhos do Professor \& Leitor as palavras de desafio de uma outra visão do saber: o da complexidade, de que Edgar Morin é o maior divulgador.

(...) se tentarmos pensar no fato de que somos seres ao mesmo tempo físicos, biológicos, sociais, culturais, psíquicos e espirituais, é evidente que a complexidade é aquilo que tenta conceber a articulação, a identidade e a diferença de todos esses aspectos, enquanto o pensamento simplificante separa esses diferentes aspectos, ou unifica-os por uma redução mutilante. Portanto, nesse sentido, é evidente que a ambição da complexidade é prestar 
contas das articulações despedaçadas pelos cortes entre disciplinas, entre categorias cognitivas e entre tipos de conhecimento. De fato, a aspiração à complexidade tende para o conhecimento multidimensional. Ela não quer dar todas as informações sobre um fenômeno estudado, mas respeitar suas diversas dimensões: assim como (...) não devemos esquecer que o homem é um ser biológico-sociocultural, e que os fenômenos sociais são, ao mesmo tempo, econômicos, culturais, psicológicos etc. Dito isto, ao aspirar à multidimensionalidade, o pensamento complexo comporta em seu interior um princípio de incompletude e de incerteza (MORIN, 1998, p. 176-177).

Nas palavras do filósofo e educador, renasce a esperança do professor: então não se trata de separar para entender. É preciso articular para compreender. Mais do que isso, é preciso especular, descobrir no movimento suas engrenagens e pensar dialeticamente que a maior aproximação do que se considera o saber pode corresponder à descoberta de lacunas e vaguezas, apontando para a necessidade constante de ampliação das pesquisas e do aparecimento de mais e mais perguntas.

Sem que se dê conta, o pequeno dicionário sofre nas mãos do Professor \& Leitor, envolto pelo silêncio da biblioteca, as conseqüências da concorrência entre a escola e a televisão. Ele o segurava com a força de um braço guerreiro. Estava disposto a tomá-lo como arma de combate contra o inimigo eletrônico e colorido. Olhou de esguelha para os lados, buscando na biblioteca pessoas espantadas. Mas ninguém olhava para ele. Ou deveria dizer infelizmente ninguém o olhava? Poucas situações são mais tristes do que uma biblioteca sem leitores. Nada mais justo que tivesse sido a Filosofia a responsável pelas associações e reflexões a que ele havia chegado.

Observando melhor, percebeu que ninguém o olhava proximamente, porque ao longe surpreendeu os olhos da bibliotecária pousados interrogativamente sobre ele Abandonando a abstração que o dominara, tomou consciência de seu corpo e descobriu-se totalmente apoiado na estante, como que a representar sensorialmente a incessante busca do conhecimento guardado nos volumes alinhados. Assim o corpo que traía seus pensamentos também atraía o olhar da bibliotecária. Resolveu abandonar a posição; um pouco para descobrir novos enfoques, um pouco para fugir do foco de observação. Desaguou na área da Psicologia.

Envolvida por títulos e autores que passaram a integrar o cotidiano de todos os intelectuais, e mesmo o cotidiano das classes $\mathrm{C}$ e $\mathrm{D}$ via programas das tardes da TV, em que psicologia e "psicoachismo" se equivalem. Curioso, retira alguns volumes das estantes. Falam da psique, de símbolos, energia, traumas, recalques, ego e inconsciente. São extremamente atraentes nas interpretações sobre o mundo e, principalmente, sobre o homem. 
Folheia ao acaso um dos volumes. Na página sob os olhos, descobre um fragmento atraente:

(...) a ciência se preocupa com o saber e com as necessidades do saber (...) Aquilo que for acessível à direta observação física exterior e que possa ser compreensível e significativo para o pensamento racional não tem na realidade qualquer necessidade de abordagem simbólica. Mas, para aquelas áreas da experiência que respondem apenas às abordagens intuitiva e emocional - e isso abrange uma parte muito grande e fundamental da experiência humana - a abordagem simbólica é apropriada porque é a única abordagem prática. À medida que progredimos no mundo dos simples fatos exteriores para dentro dos dinamismos mais íntimos da psique inconsciente, atingimos domínios nos quais nosso entendimento lógico não é mais suficiente; ele não nos ajuda a ir além. (WHITMONT, S.d., p. 28-29).

O conhecimento a respeito do objeto ser humano nos conduz, portanto, para mais próximo do simbólico, sem abandonar o empirismo e o racionalismo. Trata-se de uma nova dimensão do conhecimento que tenta dar conta das experiências do mundo interior. Outra não é a interpretação atribuída ao sonho, concebido

(...) como um mito fragmentado ou personalizado (...)[ por sua vez] o mito (e aqui incluímos também o conto de fadas) poderia ser considerado um sonho conscientemente moldado ou despersonalizado.(...) Os mitos aparecem natural e espontaneamente nas lorotas e nas histórias narradas especialmente pelas crianças (Idem, p. 69).

Aprendemos que o mito tem suas próprias leis: trata-se de um relato de acontecimentos ocorridos no instante primordial, de origem, num tempo sagrado. Ao recontá-lo, o narrador reatualiza esse tempo sagrado; e o momento da narração cria um tempo não-temporal, um instante sem duração, como alguns místicos e filósofos imaginam ser a eternidade (ELIADE apud WHITMONT, p. 69-70).

Não apenas essa narração recria o espaço platônico da reminiscência, como solicita uma disponibilidade para a aprendizagem que abra espaço para um saber diferente porque, na origem, no passado remoto, "a idéia de fé no sentido de crença não existia; para eles era uma questão de 'saber'. Isso porque, para aqueles que 'sabem', o inexprimível pode ser enunciado sem ser entendido erroneamente" (WHITMONT, p. 71). Qualquer desconfiança, ou qualquer necessidade de explicação, pode transformar o mito em fórmula dogmática, em mentira, em caricatura. É preciso acreditar nele porque "Dotado de dignidade e de majestade, perfeito em sua validade e poder interior, é a 
única linguagem adequada para aquilo que podemos apreender apenas através da fé e através de nossa ação no mundo físico". Tanto para poderosas realizações positivas quanto negativas, os mitos atravessam os séculos como 0 fizeram os mitos de Idade de Ouro (presentes em Karl Marx), o mito do messias-herói que alimentou Hitler e levou a humanidade ao horror da guerra e do genocídio, os mitos aquáticos, os da Sombra ou de Afrodite - com Xuxa, Angélica e Juliana Paes inclusas neste último.

Mesmo que mantenhamos uma distância crítica respeitosa, não podemos deixar de reconhecer a força de uma imagem mítica como a da mulherGea, a mãe Terra, exemplificada no texto abaixo, de Eduardo Galeano, localizado no tempo em que os negros cimarrões - termo que significa "flecha para a liberdade"- lutavam por seus direitos na América Holandesa.

\section{ELAS LEVAM A VIDA NOS CABELOS}

Por mais negros que crucifiquem ou pendurem em ganchos de ferro que atravessam suas costelas, são incessantes as fugas nas quatrocentas plantações da costa do Suriname. Selva adentro, um leão negro flameja na bandeira amarela dos cimarrões. Na falta de balas, as armas disparam pedrinhas ou botões de osso; mas a floresta impenetrável é o melhor aliado contra os colonos holandeses.

Antes de escapar, as escravas roubam grãos de arroz e de milho, pepitas de trigo, feijão e sementes de abóbora. Suas enormes cabeleiras viram celeiros. Quando chegam nos refúgios abertos na selva, as mulheres sacodem as cabeças e fecundam, assim, a terra livre (GALEANO, 1985, p. 30).

Emergindo desse mundo ancestral, o Professor \& Leitor descobre-se de volta ao corredor da biblioteca. Agora são dois pares de olhos sobre ele. Um par de namorados indaga:

- O senhor está bem?

- Por que perguntam? Indaga em troca.

- É que pedimos licença para passar e o senhor nos olhou sem ver, parecia estar em outro tempo...

- Estou bem, estou bem, obrigado., responde sem alongar-se em explicações.

Encolhe-se junto à estante para que possam passar e sorri. Para que entendessem o que ele experimentara, seria necessária uma longa explicação. Deixa que pensem ser apenas um sintoma de velhice. De qualquer forma, os mitos também são antigos... E Eros, o deus travesso, já brincava com eles dois o suficiente para lhes causar os desassossegos do amor.

Mas o mergulho em regiões interiores trouxe-lhe à lembrança um outro mito, o de Fausto, em quem o conhecimento científico vive o intenso conflito com o desconhecido. Dessa esfera, sobressai a tendência para a ma- 
gia, recurso utilizado para dar conta do inexplicável, do intuível, do inexprimível. Ouçamos a personagem clamar do mais íntimo do seu ser o desespero de encontrar-se frente à inutilidade de uma vida de estudos, em que celebrara continuadamente o conhecimento intelectual e abdicara dos prazeres sensoniais.

Estudei com ardor tanta Filosofia,

Direito e Medicina,

E infelizmente até muita Teologia.

A tudo investiguei com esforço e disciplina, e assim me encontro eu, qual pobre tolo, agora (...)

Dez anos a ensinar, autêntico impostor

A subir e a descer por todos os lados

Estudantes à volta de mim sempre grudados

E chego ao fim de tudo ignorante em tudo!

Coração a ferver! Para que tanto estudo!

Não tenho mais saber que os tolos e doutores,

Nem sei mais que os Mestres, padres e escritores.

Dúvidas? Escrúpulos? De tudo já dei cabo.

Não mais me assombra o inferno e nem mesmo o Diabo,

Fugiu todo o prazer da minha adolescência,

Não me interessa mais do Direito a ciência,

Nem tampouco a tarefa árdua de ensinar,

Aos homens converter e tanto doutrinar.

Dinheiro não ganhei, não tenho quase haveres,

Nem a glória do mundo e seus doces prazeres;

Por que tanto viver como se fora um cão!

Apego-me à magia. É uma salvação.

Por força do espírito e o vigor do verbo,

As forças naturais, secretas, exacerbo,

Que com amargo esforço eu tentei revelar

Não conseguindo nunca a verdade alcançar.

Por fim, conheço hoje, o que em todo o mundo,

Existe de mais íntimo e de mais profundo,

As forças criadoras, forças embrionárias,

Que palavras não exprimem tão tumultuárias. (GOETHE, 1976, p. 29-30).

No desabafo da personagem reconhecemos um tanto de nossos embates pessoais no trato com a educação. Divididos entre alunos e livros, representantes do conhecimento em formação e do conhecimento estratificado, tornamo-nos conhecedores de outra verdade, a da incapacidade de dar conta, no espaço de uma só vida, do escrito e do vivido, do que é alheio a nós e do nosso eu mais íntimo, do público e do privado, da razão e da intuição. Temos a personagem confrontada com um saber restrito à natureza e aos atributos dos objetos que são vistos em sua individualidade, para só mais tarde serem 
relacionados uns aos outros. O domínio desse saber constituído descobre-se afinal um engano, um engodo, pois o mais sábio iguala-se ao mais tolo. Da mesma forma, a magia passa a ser um segundo caminho, abandonado o primeiro. Ainda é exposta pela personagem uma noção de ciência compartimentada, não dialética. A visão dialética implica que os processos de conhecimento considerarão sempre o conjunto e a unidade universal, de onde decorrem todas as relações entre objetos e sujeito.

"A ciência não é uma coleção de leis, um catálogo de fatos não ligados entre si. Ela é uma ação do espírito humano por via de idéias e conceitos livremente inventados" no dizer de Caio Prado Júnior (1990, p. 37). Por isso, Fausto se encontra no limiar do homem novo no início do século XIX, que busca, por ângulos novos, considerar velhos problemas, como o esgotamento da ciência, a aceitação do inefável e do desconhecido como fontes de saber, e a separação do intelectual da vida sensorial. Fausto é a encarnação do ser humano, impotente face à multiplicidade do mundo. É o rebelde, o problemático, o dilacerado, o ser consciente de sua minoridade no Universo.

A evocação do Fausto impulsiona vigorosamente o Professor rumo às estantes da literatura. Intencionalmente evita interromper o trajeto parando nas Matemáticas, na História e na Lingüística. As narrativas míticas lhe forneceram o motivo para buscar nos textos literários outra forma de expressão simbólica. Ao deparar-se com o acervo disposto nas prateleiras, reconhece que, desde os primeiros passos naquela biblioteca, era para lá que desejava ir. Mesmo sem ter definido o objeto último da busca, descobria agora que era nesses textos ficcionais que buscava a resposta à indagação o tempo todo latente: que relações estabelecem entre si a leitura e o conhecimento?

O discurso literário, cuja linguagem utiliza a palavra na função poética, a mais abrangente e intencional de todas as funções lingüísticas, se organiza por meio do diálogo entre os variados discursos. Ocorrência a que Bakhtin denominou dialogismo. A multiplicidade é, portanto, sua face mais característica. Assim sendo, o discurso científico está contido na literatura. Principalmente no duplo funcionamento do empírico e do racional. Quanto a este último, está presente tanto na sua feição realista - apoiada no objeto sobre 0 qual narra - quanto na feição idealista - apoiada no sujeito que narra.

Emergiam da memória do Professor \& Leitor esses conceitos, enquanto os dedos vasculhavam com amorosa lentidão os volumes cujos títulos excitavam o imaginário: As Cidades Invisíveis, O Livro dos Abraços, A Montanha Mágica, No Urubuquaquá, no Pinhém, A República dos Sonhos. Quantas viagens, quanto aprendizado! Mundos vistos com o olhar interior, palavras a construir realidades. Exaltação à mente humana capaz de criar no vazio da página a complexidade do Universo. A viagem no espaço dos livros conduzira ao porto do imaginário. De olhos fechados, segue ao acaso com as mãos. 
Tateia em busca do absoluto aleatório. Cada objeto é convertido em manifestação do Destino e da Criação. Penetram pelos poros da pele os signos de linguagens outras: a espessura, a rugosidade, a maciez, o formato, o peso. A mente processa as informações táteis em um programa tão antigo quanto o homem: a memória. Ecos de leituras passadas repercutem nos espaços entre livros. Os dedos lêem recordações de outros tateares. A biblioteca interior forceja em vir à tona. É como se cada volume tocado tocasse as fibras e cordas de velhas leituras, atualizando músicas novas e ainda enfeitiçadoras. Dedilha um volume em que ressoa a infância. As letras do título infiltram-se entre as pálpebras cerradas: entrevê Corda Bamba, de Lygia Bojunga. particular":

As páginas se abrem para a passagem do fragmento do capítulo "Aula

Maria começou a escrever. O olho escapou pra baixo da mesa. O cachorro tinha parado de morder a borracha, mas em compensação a borracha tinha sumido. $\mathrm{O}$ que é mesmo que ela tinha que escrever?Ah! Antes ela tinha feito errado, bom, se antes tava errado o jeito era fazer ao contrário. Mas será que ele tinha engolido mesmo a borracha? Firmou o olho no caderno e acabou de escrever.

- Tá certo, Dona Eunice?

Dona Eunice suspirou "até que enfim" e começou a explicar matéria nova. Maria ficou olhando pra ela. Só quando Dona Eunice olhava pro livro é que Maria olhava pro chão. O cachorro não se mexia. De tanto encolher a perna, Maria começou a sentir o pé dormente. Dona Eunice explicava, explicava, mas o cachorro não se mexia mais e, de repente, o coração de Maria deu um pinote: vai ver engasgo de borracha não fazia barulho! e se o cachorro tinha se engasgado baixinho? e momido bem baixinho? Dona Eunice falava, escrevia, a dormência do pé foi subindo, subindo, Maria já não sentia a perna direito, por quê que a Dona Eunice tinha virado o caderno pra ela?

- Você vai efetuar essas adições e subtrações de frações com denominadores iguais e desiguais.

Fração? Mas elas não estavam em número divisível?

- Mas, olha, Maria, eu quero que você use o MMC.

- MMC? ( Ai, como a perna tava esquisita! Como ia ser bom sacudir ela bem.)

- Menor múltiplo comum. Ou será que você já esqueceu?

- Não esqueci, não. (Mas de que jeito? Se sacudia a perna, ela batia no cachorro.)

- E o MDC?

- MDC? (E se a perna batia ... e o cachorro, não mexia?)

- É.

- Que que tem?(Bom, se ele não mexia...)

- Você está lembrada do MDC? 
- Tô, sim senhora. (... é porque tinha mesmo morrido baixinho.)

- Então vamos ver: faça aí as operações (NUNES, 1987, p. 54-55).

Nem sempre se evidencia tão claramente a relação entre o conhecimento científico - neste caso a matemática, e o conhecimento do mundo neste caso a associação da imobilidade à morte, e a interpretação dos dois.

É freqüente ouvirmos de professores e pais que se deve ler para obter informações mais corretas e atualizadas. Ler é o instrumento indispensável para a cultura - entendida como um acúmulo de informações, por vezes desordenadas e sem utilidade. Ler ainda é um substituto do professor, concebido como repassador de um saber alheio, repetidor de dados que lhe foram confiados ao longo do período de formação profissional.

Vista desta maneira, a relação entre leitura e conhecimento acaba por atribuir ao livro uma função reafirmadora de valores, pragmática e instrumentalizadora. É verdade que a amplitude de funções dos discursos verbais escritos também comporta esta finalidade. Mas não exclusivamente. 0 leitor de jornal se posiciona diante do escrito de forma diferenciada daquela do leitor de livros. A leitura do livro didático pressupõe atitudes e comportamentos em princípio não previstos na leitura literária. A informação sobre o enfarte, por exemplo, num jornal, numa revista especializada em cardiologia, num livro de anatomia ou em Machado de Assis são acreditadas em níveis e intensidades diversas.

Da mesma forma, MMC e MDC, além de siglas, evocam informações particulares em cada sujeito e sua apreensão está condicionada a contextos específicos. Maria, no texto de Lygia Bojunga, associa a matemática à angústia de um cachorro amedrontador, mas adormecido a seus pés. Associa, ainda, a noção de morte à de silêncio e à de maciez e quietude de uma borracha; acaba produzindo um conhecimento híbrido e poético, embora assustador para a personagem: 0 da morte baixinho.

A literatura, em sua multiplicidade, aceita associações das mais corriqueiras às mais bizarras, com a naturalidade da invenção e com a ousadia da antevisão, próprias da arte. Lembremos de Júlio Verne e seus inventos - à época maravilhosos - hoje ultrapassados pelos avanços da inteligência e da operosidade humanas..

Afinal, o diálogo entre a realidade, composta pelos objetos, e o sujeito, tenha ou não um formato escolar, chega sempre a uma conclusão inevitável: o conhecimento se realiza também nos interstícios do texto escrito e na anexação, ao sentido usual, de experiências vitais particulares. Folhetos turísticos, o senso comum e a vida podem resultar em novas categorias de aprendizagem, como se pode verificar num fragmento de Que raio de professora sou eu?, de Fanny Abramovich: 
Inventei um teste.

ASSINALE O VERDADEIRO (V) OU FALSO(F)

Numa excursão pro sul do Brasil:

a) A alegria reina. O ônibus respira felicidade e animação.

b) Se tem a oportunidade de conhecer pessoas interessantes, divertidas, vividas.

c) Há uma grande chance de se arrumar um namorado.

d) A pessoa com quem vai dividir o seu quarto durante os vinte dias é ótima companhia. Cabeças e vontades afinadas.

e) Tudo transcorre bem. O guia é ótimo, os hotéis confortáveis, a comida gostosa, os horários bolados pra se conhecer bem todos os lugares. Bem planejado como garantia o folheto.

RESPOSTA - Todas as respostas são verdadeiras e falsas. Ao mesmo tempo. Fiz essa viagem. Há uns anos. No ônibus, velhas senhoras e idosos cavalheiros alegres e piadistas, crianças choronas, mães histéricas. De matar! Arrumei um namorado e terminei com ele, antes do final da viagem. Era um chato completo. A senhora que dividiu o quarto comigo lembrava minha avó. Só faltava me pôr de castigo. Queria saber tudo que eu tinha feito longe de seus olhos. Com detalhes. Mas era boa gente, tadinha... Em alguns lugares foi bom ter ido. Noutros, uma lástima. A maioria só vi pela janela. Etc. e tal.

Enfim, sentimentos, atos e fatos dependem de quem conta. Questão de ponto de vista. De enfoque. (...)

P.S. Por isso tenho ataques quando vejo exercícios de História pedindo "V" ou "F". Justo pra História (ABRAMOVICH, 1990, p. 62-63).

É correta a indignação do texto ante a cegueira da escola para a realidade. Além disso, a atitude autoritária, assumida pelo sistema de educação, inibe e destrói a possibilidade da renovação e da transformação essencial. No entanto, reside exatamente na mudança a saída para o conhecimento, questionado e questionador, capaz de alterar o sistema bancánio da informação e da avaliação num processo social libertador. A voz de Brecht se impõe no canto a um mundo novo:

Em vez de serem apenas bons, esforcem-se

Para criar um estado de coisas que tome possível a bondade

Ou melhor: que a torne supérflua!

Em vez de serem apenas livres, esforcem-se

Para criar um estado de coisas que liberte a todos

E também o amor à liberdade

Torne supérfluo!

Em vez de serem apenas razoáveis, esforcem-se

Para criar um estado de coisas que tome a desrazão de um indivíduo

Um mau negócio! (BRECHT, 1986, p. 136). 
O Professor \& Leitor toma consciência da realidade ao deparar com a expressão surpresa e boquiaberta da bibliotecária. Ele havia depositado sobre o balcão de empréstimos dezenas de volumes. Não sentia nos braços o peso que sustentara ao longo da travessia das estantes. Dentro dele, no entanto, tomava corpo cada vez mais, sólido e poderoso, um saber que ultrapassava a concepção habitual de conhecimento. A convivência com os livros mais uma vez engravidava sua visão do mundo e ele chegava ao final de mais uma viagem com o olhar pacificado, esperançoso e, ainda assim, indescritível das grávidas. Preparava-se para parir um texto.

\section{Referências}

ABRAMOVICH, Fanny. Que raio de professora sou eu? São Paulo, SP: Scipione, 1990.

BORGES, Jorge Luís. História da eternidade. São Paulo, SP: Globo, 1991.

BRECHT, Bertolt. De que serve a bondade. In: e trad. de Paulo C. Souza. São Paulo, SP: Brasiliense, 1986.

. Poemas: 1913-1956. Sel.

DROZ, Geneviève. Mitos platônicos. Portugal: Europa-América, s.d.

GALEANO, Eduardo. As caras e as máscaras. Rio de Janeiro, RJ: Nova Fronteira, 1985.

GOETHE, J. W. Fausto. Trad. Sílvio Meira. São Paulo, SP: Abril Cultural, 1976.

LOBATO, Monteiro. Aritmética da Emília. 15. ed. São Paulo, SP: Brasiliense, 1974.

. Serões de Dona Benta. 11. ed. São Paulo, SP: Brasiliense, 1977.

MORA, José Ferrater. Dicionário de Filosofia abreviado. Buenos Aires: Sudamericana, 1970.

MORIN, Edgar. Ciência com consciência. 2.ed. Trad. Maria D. Alexandre; Mạ Alice S. Dónia. Rio de Janeiro, RJ: Bertrand do Brasil, 1998.

NUNES, Lygia Bojunga. Corda bamba. 10. ed. São Paulo, SP: Agir, 1987.

PRADO JR, Caio. A dialética do conhecimento. 2. ed. São Paulo, SP: Brasiliense, 1980.

WHITMONT, Edward C. A busca do símbolo: conceitos básicos da Psicologia Analítica. São Paulo, SP: Cultrix, s.d. 